ENVIRONMENTAL MIGRANTS AND CANADA'S REFUGEE POLICY

$$
\text { by }
$$

Sheila Murray, BA, Ryerson University, 1996

\author{
A Major Research Paper \\ presented to Ryerson University \\ in partial fulfillment of the requirements for the degree of \\ Master of Arts \\ in the Program of \\ Immigration and Settlement Studies
}

Toronto, Ontario, Canada, 2010

(C) Sheila Murray 2010 
Author's Declaration

I hereby declare that I am the sole author of this major research paper.

I authorize Ryerson University to lend this major research paper to other institutions or individuals for the purpose of scholarly research.

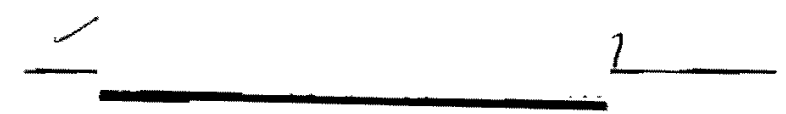

Signature

I further authorize Ryerson University to reproduce this major research paper by photocopying or by other means, in total or in part, at the request of other institutions or individuals for the purpose of scholarly research.

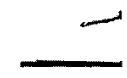

1

Signature 


\title{
ENVIRONMENTAL MIGRANTS AND CANADA'S REFUGEE POLICY
}

\author{
Sheila Murray, \\ Master of Arts, 2010 \\ Immigration and Settlement Studies \\ Ryerson University
}

\begin{abstract}
Canada is among the world's foremost refugee resettlement countries and is signatory to international agreements that affirm its commitment to the protection of refugee rights. Asylum seekers come to Canada from around the globe. But as climate change continues to affect growing regions of the world-threatening to create as many as 200 million environmental migrants by the year 2050 - Canada has not yet begun to address the issue of climate change migration. In an era defined by a neo-liberal approach to migration issues, and until international actors determine the status of environmental migrants, Canada's policy response to the looming crisis may be conjectured from an historical review of its refugee policy. This provides an understanding of the various factors, both domestic and international, that may have the greatest influence on Canada's future refugee policy.
\end{abstract}

Key Words

Environmental migrants; history of Canadian refugee policy; Australian refugee policy; humanitarianism; UNHCR; 


\section{ACKNOWLEDGEMENTS}

I'd like to thank my supervisor Chris Gore for teaching me about policy learning, and for his interest and commitment to the idea that formed this paper. And many thanks to my second reader, Myer Siemiatycki, for his inimitable enthusiasm and support. 
Table of Contents

Introduction 1

$\begin{array}{ll}\text { Methodological approach } & 6\end{array}$

Climate Change, its relationship to migration, $\quad 8$

and an approach to assessment

$\begin{array}{ll}\text { Environmental Migrants: a global overview } & 10\end{array}$

$\begin{array}{ll}\text { Canada } & 20\end{array}$

Background to UNHCR \& Canadian refugee policy: historic 21 and comparative perspective to 1950

The UNHCR

Refugee protection from 1950 to mid-70s 28

Vietnamese boat people and the decline of UNHCR influence 32 mid-1970s to mid- 1980 s

Boat invasions: security as the new refugee policy norm 38

The National/Human Security discourse $\quad 41$

Environmental migrants: Contemporary discourse in Canada, $\quad 47$ Australia, and the EU

Looking ahead: Canada's prospect for change 52

References $\quad 57$ 
Nature may be viewed parochially from the perspective of the nation-state's territory and the ability of the ecology to support the existing population. Nature may also be viewed globally from the perspective of world ecology and the right of all individuals, including future generations to have access to the essentials of life. In either case, the pre-eminent value in determining justice claims is the preservation of an ecological balance. The goal sought is survival (Adelman, 1994, p.73)

\section{Introduction}

Ayesha Kabir is an attractive woman in her 30s. She is the editor of PROBE Magazine, published in Dhaka, Bangladesh. Her English is very good. She is educated, sophisticated, and clearly fired by the courage of her convictions. In an interview with a Canadian based filmmaker about the effects of climate change in Bangladesh she delivers a message that all Canadians should hear:

"There are large tracts of land all over the world that are empty. And over here we struggle on this tiny area of land and [are expected] just, you know, like osmosis, to go over into India. That doesn't seem right to me. I think they [affluent nations] have a responsibility. I think they have a responsibility to [house] these people too."

Bangladeshis have always coped with floods that cause about 500,000 people to move every year. But they are barely coping now, and the future, exacerbated by climate change, will be near impossible to control. The effects of climate change on Bangladesh's densely populated low-lying regions that extend $100 \mathrm{~km}$ inland from the coast compound upon each other. Flooding contributes to riverbank erosion and an increased number of severe cyclones trigger storm surges that cause further flooding and erosion. The sea comes ever closer for the roughly 75 million

\footnotetext{
'Does anyone care if Bangladesh drowns? Documentary film made in Bangladesh by Canadian based filmmaker, Afsan Chowdhury.
} 
people who live less than 12 meters above sea level. Subsequent migration within Bangladesh could stress the social, economic and political structures to such a degree that regional security would be compromised (Warner et al, 2009, p.13).

Bangladesh has a population of about 150 million. Around 12 million of those live in the capital city of Dhaka, and another 500,000 arrive each year. According to the International Organization for Migration (IOM), ${ }^{2}$ about 70 per cent of Dhaka's poorest inhabitants have abandoned unsustainable agricultural and fishing practices to try and survive in the city (Friedman, 2009).

Dhaka is full up. And this is where the crisis accelerates, because by the middle of this century as many as 25 million Bangladeshis are at risk of displacement because of climate change (Myers, 2001, p. 611). That number, 25 million, bears repeating. It represents a mere fraction of the estimated number of people who will be forced to move globally because of climate change by 2050 (Myers 2001; IOM 2007; Stern 2006).

Despite the "outward manifestation of profound deprivation and despair" that populations displaced as a result of persistent ecological change represent, the international community has failed to deliver any adequate response (Myers, 2002, p.611). Myers points to the indifference of the developed world that regards distant population migrations as a "peripheral concern" ( $p$. 611). In the meantime, industrialized and newly industrialized states continue to build regional networks of security between themselves and the asylum seekers who make increasingly risky journeys between their countries of origin and their destinations. For example, India is building an eight-foot high, 2,500 mile long, barbed wire fence between itself and Bangladesh (Nelson, 2005). While its stated rationale for the barrier is to counter a terrorist threat, it is clearly not

\footnotetext{
${ }^{2}$ The principle inter-governmental organization responsible for delivering services and advice to governments and migrants.
} 
disposed to accepting large numbers of Bangladeshi refugees. India is poor and densely populated. And like most other countries in the world, India will have its own domestic climate battles to fight.

While Myers uses the term environmental refugee, the term environmental migrant appears to have gained currency in the last few years. Other terms employed by the authors whose work is cited in this study, such as climate refugee or climate change refugee, will appear throughout this paper. Warner et al (2009) offer the following definition that is also used by the IOM. There are no international norms or obligations attached to this definition.

Environmental migrants are persons or groups of persons who, for compelling reasons of sudden or progressive changes in the environment that adversely affect their lives or living conditions, are obliged to leave their habitual homes, or choose to do so, either temporarily or permanently, and who move either within their country or abroad (Warner, 2009, p.2).

In the developing world there is a profound lack of capacity to deal with the social, economic and political problems associated with climate change and forced migrations. Developing states are demanding more funding for climate adaptation and mitigation strategies, as well as aid in return for hosting regional migrant populations. Estimates suggest that there were already 25 million environmental refugees in 1995 (Myers, 2001). In the meantime, the developed world has failed to agree upon the fundamentals that might slow further climate change, and Kyoto objectives have not been met. The Canadian government's position on climate change has been one of "studied indifference" (Flannery, 2009). In Canada, the rapidly growing public awareness of climate change has tended to emphasize the ways in which economic growth can be "greened."

While the international community considers its response to environmental migrants, Canada's political parties appear neither to have begun their own deliberations nor to have 
engaged Canadians in any discussion. At its annual conference in August 2008 the Institute of Public Administration of Canada (IPAC) made the following spare recommendation: "The Canadian government should collaborate on developing a policy to deal with anticipated "climate change refugees" (p. 8). The report proposes that the collaboration should be among both regional and international actors. This paper goes beyond IPAC's recommendation and asks: Given the absence of any formal law, regulation, government statement or policy that directly articulates a position on environmental migrants, do any international or domestic factors have the potential to produce (either formal or ad hoc) change in Canadian refugee policy that recognizes (or refuses) any special status for people whose migration and permanent displacement is directly linked to climate change?

According to Myers (2001), environmental refugees "rank as one of the foremost human crises of our times" (p. 611). But Canada has not yet been challenged, either domestically or internationally, to develop a policy on environmental refugees. The explanations for this may be manifold, but in this paper I will explore four factors that could lead to the inclusion of environmental migrants in the political and public discussion of refugee policy and produce specific policy on environmental migrants: 1) an international agreement on the status of environmental migrants; 2) international moral pressure; 3 ) a rejection of the emerging conflation between humanitarianism and national security; and, 4) pressure resulting from strong domestic pressure.

Canada's historical record shows that it has the potential to become an international leader in environmental migrant policy, either by working with the international legal community to create a legal framework for environmental migrants and/or establishing its own domestic policy to allow for the resettlement of environmental migrants. Conversely, it could 
choose to draw from the policy models of other developed nations and enhance existing exclusionary practices for asylum seekers. In this paper I argue that neither international nor domestic pressure is likely to influence Canadian policy. Instead, the existing lack of policy action or debate, combined with the actions the Canadian government has taken, suggests that Canada will likely adopt - implicitly or explicitly - an exclusionary response to environmental migrants.

Canada did not have a formal domestic refugee policy until 1976. Its adoption of policy at that time was a result of international learning and mimicry. Its non-discriminatory humanitarianism was learned from the example of other developed states that were guided by the United Nations High Commissioner for Refugees. Canada was able to stand apart from the UNHCR until public and media sentiment steered it toward parallel international action. In recent years, developed states have challenged the UNHCR's moral and expert authority, in part by withholding, or by earmarking ${ }^{3}$ financial support. However, Milner (2008) argues that while Canada has not been the most generous donor, it has taken the lead in a move away from earmarking (p.10).

I will begin this study by outlining my methodological approach. A contextual account of current climate change concerns will follow. I will then provide a review of the debate that surrounds the creation of a legal framework for environmental migrants, either by expanding the Convention definition or through an entirely new protocol. Following this I will outline a history of the Canadian refugee regime and identify the drivers of change that prescribe lessons for contemporary Canadian policymakers. A brief account of the activities and achievements of the UNHCR will be included, along with an assessment of the influence of the UNHCR on the

\footnotetext{
${ }^{3}$ The EU, US and Japan earmark 100 per cent of their UNHCR donations for a region, country, or theme. 80 per cent of all donations to the UNHCR are earmarked (Milner, 2008, p. 10).
} 
international refugee regime through to its peak authority in the early eighties and the subsequent, diminishing moral authority of the UNHCR over its member states. A discussion of the current emphasis on security by the developed nations and the UNHCR and the manner by which they have conflated humanitarianism with security will follow. This will include an account of the levels of interception and interdiction that characterize today's refugee regime in the developed world - one of containment and exclusion - with particular attention to Canada's participation. Finally, I will review Canadian discourse on environmental migrants over the last two years and contrast this with a brief description of current environmental migrant issues in Australia and the EU.

\section{Methodological approach}

My study endeavors to evaluate factors that may influence Canada's future response to an emerging issue. At the same time, it is directly informed by Canada's past response to refugees. Therefore, in this paper I conceptualize and hypothesize based on learning from Canada's actions in response to past events.

The policy of a national government can be influenced by domestic factors, but also by its relationship with other states and international organizations. For example, in her study of how national interests are learned from international actors, Finnemore (1996) notes that "[T]he definition of the "problem" and the strategies for solving it came from international organizations and the individuals who created and ran them" (p.13). This parallels the work of other scholars in the area of policy convergence and diffusion who note that international imposition, as well as emulation, are often important drivers of domestic policy actions (Barnett \& Finnemore 1998; Knill 2005). 
Constructivists theorize that states are embedded in transnational and international social relations that shape their role in the world. They are socialized to want certain things, and power and wealth are means, not ends. Internationally held or communicated norms also influence citizens, who, in turn, influence states (Finnemore 1996; Knill 2005). Likewise, policy diffusion occurs when national policy-makers voluntarily adopt policy models that are communicated internationally (Knill, 2005). For example, the diffusion of international norms promoted by the UNHCR in Canada and Australia were important reasons for both countries dropping immigration and refugee policies that discriminated on the basis of race. Both countries have since contracted to a number of similar international and supranational agreements. But domestic events also influence policy makers. In my study I will show how comparable refugee events in a domestic setting of both Australia and Canada tend to have similar policy outcomes. In recent years domestic state interests have also influenced the UNHCR which in turn has set new international norms. Hence, the influence of international norms on domestic policy is not unidirectional, and international organizations are also vulnerable to domestic pressures for change as promoted by their members.

My observations emerge from both scholarly and grey documents as well as media reports. My research has focused on changes in national political and public discourse and/or concrete changes in refugee policy. Very often the government of Canada's response to refugee issues is based on a reading of the public sentiment at a given period of time. My search of the data will identify public sentiment as well as describe the formal government response. 


\section{Climate Change, its relationship to migration, and an approach to assessment}

On December 7, 2009, stakeholders will meet in Copenhagen in order to determine a set of goals that will take them beyond the Kyoto Protocol. Whatever the outcomes of Copenhagen, it is certain that public awareness of the imminent and varied levels of threat to population security will be heightened.

In order to escape the worst scenarios implied by climate change the world must reduce its greenhouse gas (GHG) emissions to between 50 and 80 per cent below 1990 levels - figures proposed by scientific consensus and tabled by the Intergovernmental Panel on Climate Change (IPCC). ${ }^{4}$ While scientists continue to be surprised by the accelerated rate of climate change, recent findings warn that GHG emissions above 350 parts per million could tip the climate into a mode that will warm the world beyond the universally recognized safe level of 2 degrees. Scientists estimate that the world will reach 390 parts per million by the first half of 2010 .

Even if the world manages to slow climate change to manageable levels by reductions in GHG emissions or through geo-engineering, ${ }^{5}$ there will continue to be those who are displaced, or who have their daily access to sustenance threatened by climate change. This is because even if the world dramatically reduced emissions tomorrow - the emissions that exist in the atmosphere today will continue to affect the global climate since they can persist in the atmosphere for decades.

According to the UNHCR, in the last 20 years natural disasters have increased from 200 annually to more than 500 . "Nine out of every ten natural disasters today are climate-related

\footnotetext{
${ }^{4}$ General agreement among world leaders is that global warming should be contained at or below $2^{\circ} \mathrm{C}$ above preindustrial levels.

${ }^{5}$ Geoengineering is defined as "a purposeful human activity that significantly alters the state of the Earth." (sic).(Lovelock 2009) In the battle against global warming, three main technological strategies include: limiting the amount of sunlight that reaches earth; carbon capture, and carbon storage.
} 
[and]... as many as 20 million people may have been displaced by climate-induced sudden-onset natural disasters in 2008 alone." 6

By the year 2050 the world could have as many as 200 million environmental migrants whose forced displacement from their homelands will be definitively linked to climate change (Brown 2008; Myers 2002). ${ }^{7}$ If these projections are to be believed, then Canada, with all of its "vast tracts of land," will become a manifestly desirable destination for a large diversity of people from around the globe. Further, if climate change proves impossible to control some scientists and researchers anticipate a future in which a handful of countries will become the only possible refuge for enormous numbers of people who are desperately in search of any relatively safe haven (Lovelock 2009; Flannery 2009; Dyer 2008). An extreme scenario is one in which 'lifeboat states' such as the United Kingdom and New Zealand remain inhabitable while other countries, such as the United States and Australia are not. Lovelock (2009) expects that the full impact of climate change will be a global experience by the end of this century. By then, Northern Canada will be a prime refugee destination.

Given the multitude of scenarios and factors to consider when assessing a country's response to a global issue, particularly one that bridges social, economic, and environmental considerations, the emphasis in this paper is to assess the extent to which Canada has "learned" its refugee discourse and developed its refugee policy through the experience of other regions, countries and the international community. This study will not address the science of climate change, nor any of the international or domestic technological, political or financial instruments

\footnotetext{
${ }^{6}$ UNHCR. "Climate change, natural disasters and human displacement: a UNHCR perspective" $B$ http://www.unher.org/4ad5820f9.html

${ }^{7}$ The general consensus on the number of people who will become refugees by the IPCC's marker year of 2050 is 200 million. This number is used by the United Nations High Commissioner for Refugees (UNHCR) and the International Organization for Migration (IOM).
} 
that are being developed to deal with it. Specifically, this paper provides a context with which to assess the influence of the UNHCR on the evolution of Canadian refugee policy. A discussion of Australia is included since it provides a valuable context with which to forecast the progression of Canada's future policy.

The fourth jurisdiction that provides context for this study, the European Union (EU), was not created until 1993, but it is moving toward a harmonization of refugee policies from which the developed world may take many of its lessons. Hence, this paper reflects on the experiences and influence of the UNHCR, Australia and the EU in relation to Canada. These jurisdictions are valuable to consider for the following reasons: The UNHCR was responsible for establishing a refugee regime that due to the work of successive High Commissioners has become the leading authority on refugees worldwide. Canada has drawn its moral lessons from the UNHCR and designed its own humanitarian policy response to refugee needs. Its relationship with the UNHCR has added to its international legitimacy. Canada's refugee response has also been informed by, and has informed, Australia's regime. Hamlin (2009) finds that [both] nations tend to oscillate between moments of crisis and calm in extremely reactive fashion, never able to anticipate potential pitfalls until they are occurring (p.3). These states are similar in their post colonial relationships, their patterns of settlement, and the evolution of immigration policies that initially excluded non-Europeans, but went on to foster multicultural policies. Most importantly, and unlike Canada, Australia and the EU have both had their refugee policies tested by migrants whose movement is explicitly linked to climate change. Both jurisdictions have adopted extensive exclusionary measures. While the EU seems to be in the process of developing specific policy that recognizes environmental migrants, Australia, so far, seems disinclined to do so. Therefore, I will ask, from which of these jurisdictions may Canada take its lessons? 


\section{Environmental Migrants: a global overview}

In May 2009, a group of academics and researchers led by Koko Warner from the United Nations University released a report on climate change migrants called, "In Search of Shelter: Mapping the Effects of Climate Change on Human Migration and Displacement." The authors made several fundamental observations that are supported by a variety of studies worldwide: They found that migration due to climate change is already underway; that climate change can cause the "collapse of social safety nets," which in turn fuels conflict and violence. They also observed that people who migrate because of "gradually deteriorating living conditions," are regarded as economic migrants, and as such have no recourse to any of the international instruments that differentially protect the rights of internally displaced people, asylum seekers and refugees. It is this group that is at greatest risk. They are often without the sorts of political, social or financial capital that is necessary to migration, and the impetus for migration does not resemble factors such as conflict that typically drive internal displacement. As such, they are the most vulnerable of populations - required to move, unable to maintain a livelihood, and without protection. It is for this reason that scholars have been struggling to establish a meaningful definition that identifies the special case of environmental migrants in international law. The anticipated scale of climate-induced migration intensifies the definitional problem.

Many climate change scholars measure the anticipated impacts of global warming using 2050 as a marker year. Three climate change induced outcomes that may motivate or drive migration are often highlighted: desertification, flooding, and extreme weather events (Williams 2008). While all the nations of the globe will experience climate change effects, Biermann and ina; Bose (2008) identify the regions that will be severely affected: By 2050 Bangladesh is expected to experience seawater levels that will permanently submerge more than 20 per cent of its land. 
Other states most affected by rising sea levels will be Egypt, China and India, and to a lesser degree, Indonesia, Thailand, Pakistan, Mozambique, Gambia, Senegal and Suriname. Certain island states in the Pacific and Indian oceans face the prospect of permanent elimination. Storms will force permanent displacement within the Caribbean. Drought will affect northern Mexico, and parts of South America including some of its cities. Water scarcity and drought will also afflict parts of Africa, tropical Asia, southern Europe, Australia, the USA and southern Canada.

It is anticipated that most climate migration will be contained within state borders or among neighbouring states. But forecasts anticipate environmental migrant flows from subSaharan Africa to Europe and the Middle East. Migrations from Mexico, Central America and the Caribbean are expected to travel north into the United States.

While the many sources and patterns of migrations have been identified, the debate continues as to what the people who make up these migrations should be called. Scholars have been struggling to find a definitive term to express the plight of people who are forced to migrate from their home territories due to environmental degradation since the mid-1980s (Castles, 2002). Most climate scholars claim that there is indisputable evidence of a direct link between climate change and human migration, either within state borders or across them (Myers 1993; Biermann \& Boas 2008; UNHCR 2009a). The more common terms for these migrants have been environmental migrants, eco migrants, environmental refugees, and more recently, climate refugees.

Some (Black, 2001) argue that despite the large number of climate refugee typologies used it is not possible to separate climate causes of migration from causes such as poverty, over population, political instability, land disputes, or from a multitude of other factors that have historically caused people to migrate. The criticism is that scholars who recognize climate 
refugees do so based on lack of concrete evidence to support their methodology. According to Black (2001), "despite the breadth of examples provided in the literature, the strength of the academic case put forward is often depressingly weak" (p.2). Black's findings however, deemphasize the climate change science that shows direct links between global warming, rising sea levels, desertification and environmental conflict that cause human migration. Black contains the term "environmental refugees," in parentheses implying a lack of veracity.

Jodi Jacobson is one of the earliest scholars to describe the phenomenon of environmental refugees. She identified distinct human migrations in which people leave their country of origin because their surrounding environment "no longer provides basic elements needed to sustain life" (Nash, 1999, p. 238). In 1988 Jacobson estimated that the existing number of environmental refugees was around 10 million. In 2008 , the number of environmental refugees was expected to be 200 million by the year 2050 (Biermann \& Boas 2008). Earlier estimates had determined that the 200 million figure would not be achieved until 2080 (Williams 2008). Given the significant links between climate change and forced migration, an immediate challenge arises. The international definition of a Convention refugee-with its legal obligations for protection-does not allow for the inclusion of people whose migration is for reasons of environmental degradation. Scholars are aware that the international appetite for opening the Convention is very low.

Stephen Castles (2002) warns that an expansion of the Convention refugee definition to include environmental refugees would threaten the protections given to existing Convention refugees. If expanded, the subsequent increase in the number of those deserving protection would cause governments everywhere to tighten their asylum laws. There appears to be growing agreement that an expansion of the Convention definition might not only overwhelm the 
mandate of the UNHCR but would also undermine the protections currently offered to Convention refugees (Williams 2008; Myers 1993; Nash 1999).

Convention refugees are those people who meet the definition determined by the 1951 United Nations Convention Relating to the Status of Refugees. (The 1967 Protocol expanded the Convention to include refugee events that occurred outside of Europe and after 1951.) Those who meet the terms of the definition trigger an international, legal mechanism that guarantees their protection. It also obliges signatory states not to return Convention refugees to their country of origin-the principle of non-refoulement. A Convention refugee is:

[A]ny person who, owing to well-founded fear of being persecuted for reasons of race, religion, nationality, membership of a particular social group or political opinion, is outside the country of his origin and is unable or, owing to such fear, is unwilling to avail himself of the protection of that country; or... owing to such fear, is unwilling to return to it. (Nash, 1999, p. 228)

In arguing that environmental refugees do fall under this definition, some scholars have argued that "environmental refugees" form a social group, and that "government-induced environmental degradation" is a form of persecution (Williams, 2008, p. 508). For example, the desertification of the Sahel region in Africa displaced 10 million people during the 1980s. While the national government of the Sahel might have acted to protect its population with mitigation techniques such as limiting population growth and/or increasing food production with improved agricultural practices, it did not, and the results amount to persecution. Cooper (1998) points to previous regional expansions of the Convention definition by the Organization of African States, and the Cartagena Agreement by Central American countries. Cooper (1998) also argues that existing human rights principles could be included in the existing Convention. This would allow for the refugee designation to be expanded to include persons whose fear of persecution is, "owing to degraded environmental conditions threatening his life, health, means of subsistence, 
or use of natural resources, is outside the country of his nationality and is unable or, owing to such fear, is unwilling to avail himself of the protection of that country" (Cooper, 1998). While Williams suggests that Cooper's proposal is most unlikely to gain credibility, she states, "Nevertheless, the essence of the idea remains the same: the forced relocation of individuals due to external (and largely unmanageable) factors" is a reality (Williams, 2008, p.504).

In his comparison of the theoretical positions of Myers and Black, Castles (2002) points to the functional importance of definitions that "reflect and reproduce power" (p. 9). At this time the term environmental refugees is devoid of legal meaning and is confused into a mass of typologies in attempts to identify the root cause of flight (Myers 1993; Black 1993). In his examination of findings from both Black's and Myers' studies, Castles (2002) agrees that environmental refugees are created by a multitude of causalities where environmental factors such as rising water levels and floods, persistent and severe drought, growing numbers of extreme weather events, desertification, and so on, may be linked to social, political and economic factors such as poverty, ineffectual governance, development projects, poor agricultural techniques, civil war and struggle over the control of land resources (Williams 2008; Black 1993; Myers 1993; Nash 1999). As a result, the challenge of identifying a pristine "well founded fear of persecution" becomes very difficult, and mixed migrations forced by the consequences of climate change often continue to be counted largely as economic migrations.

The terminology is critical since once established it creates obligations for national and international refugee regimes. Those who oppose a legal definition for environmental refugees would depoliticize the cause of flight by arguing that migration is an ordinary coping strategy in the face of weather events that the globe has always experienced. Drought, famine, and floods have always spurred migration. Very often those who flee are eventually able to return and 
reclaim their land and livelihoods; they adapt (Black 1993). What is missed in this characterization is the lasting nature of present day climate change-climate change scientists do not expect conditions to revert to what has previously been considered "normal." In addition, migrant populations place enormous strain on the environments in which they settle. This in turn can accelerate degradation already precipitated by climate change (Nash 1999; Myers 1993).

The political reluctance to resolve the definition debate is characterized by the absence of discourse on environmental refugees at the highest levels of the United Nations. A study by McNamara (2007) provides some insights. She suggests that the work of scholars such as Black, whose critiques emphasize multi-causalities and challenge the term environmental refugees, have allowed political actors and others to exclude the environmental from refugee research and policy. In exploring the reasons for the absence of policy on environmental refugees at the UN, she emphasizes a growing trend on the part of member states to move away from multilateralism toward regional or bilateral action. McNamara suggests that this is based on a politics of fear, fed by imagery depicting floods of desperate environmental refugees at state borders. Her examination of the discourse of policy-making used by UN ambassadors and senior diplomats revealed a growing trend toward unilateralism among the most powerful nations whose focus is currently on issues of national security. Increasing xenophobia among the public in their home states tends to support this thinking. ${ }^{8}$ While weaker, developing states must continue to rely on multilateral organizations such as the UN to advance their interests in adapting to the pressures of climate change refugees, stronger nations avoid binding international commitments and look instead at developing regional or bilateral security arrangements. Meanwhile, environmental migrants continue to be undefined. Williams (2008) argues that, "Inaction on the part of

\footnotetext{
${ }^{8}$ In South Africa, which has an estimated 3 to 5 million foreigners, refugees and immigrants from three African countries have experienced the extreme violence of xenophobic attacks (see BBC, "Refugees flee South Africa attacks", http://news.bbc.co.uk/2/hi/africa/7404351.stm
} 
governments over a given issue is still a policy position-even if the subject is defined by absence" (p.15).

Any resolution of this debate over terminology is likely to be steered by the UNHCR, which has established itself as both an expert and moral authority on refugee flows by systematically extending its jurisdiction. Over time, and despite a general lag in support for the reinterpretation and extension of the UNHCR's mandate by its member states, the UNHCR has achieved many of its objectives (Barnett \& Finnemore 2004). This has been accomplished through a process of diffusion by which member states eventually came to agree with, and to support the objectives of the UNHCR-ultimately incorporating them into their own domestic policies. Thus the humanitarian motivations, objectives and actions of the UNHCR eventually became normalized in both the national and international discourse.

While McNamara agrees that the only institution able to manage environmental refugees is the UN, others have different solutions. Additional and related debate revolves around the question of which bodies should undertake that work (Black 1993; Castles 2002). Black argues that since the term environmental refugee is rendered meaningless when it lacks specificity, priority should be given to development issues and conflict resolution. Castles too, suggests that developing countries be given greater social and economic opportunities while Northern countries should stop practices such as arms trade that hinder development in the South. This approach, however, does not address the multiple and urgent refugee crises that are anticipated by other scholars (Williams 2008; Myers 1993; Nash 1999; Biermann \& Bose 2008).

Biermann and Bose (2008) argue that the World Bank and the UN Development Program are better suited to deal with climate refugees than the UNHCR since most displacement will be internal, to regions within the refugees' countries. Migrants will need long-term strategies for 
relocation and development. As well, adaptation technologies and resources should be provided for those in areas that can be adapted so that they won't be forced to move. Biermann and Bose suggest the establishment of a Protocol on the Recognition, Protection and Resettlement of Climate Refugees under the United Nations Framework Convention on Climate Change. This would be supported by a Climate Refugee Protection and Resettlement Fund, administered through a network of existing agencies including those attached to the UN. But whichever international body or combination of institutions and agencies is given the mandate to protect climate refugees it is likely to follow a direction established by the UNHCR.

States make policy decisions at a national level. But those decisions are influenced by the policy directions of other nations and by the discourse located in the international institutions that enhance state legitimacy in the global arena. Major shifts in public policy tend to happen across transnational groups by a process of policy diffusion. Policy diffusion theorists propose that transnational norms and practices can evolve without first being set down in international agreements. Instead, they can develop through various processes such as social learning or mimetic emulation and eventually become domestic policy on a voluntary basis (Finnemore 1996; Busch \& Jorgens 2005). States may learn from the new conventions, frameworks, or protocols for the protection of environmental migrants that are currently being negotiated by scholars and lawyers alike. Once any one of these is accepted and articulated by one state, other states may follow, led by the pressure of discourse in their own states or from other state actors in the international arena.

In 2009, however, an expansion of the UN regulations governing Internally Displaced Persons (IDPs) seems more probable. The framework for IDPs emphasizes the authority and duty of the nation-state to its nationals who are displaced within its borders. The UNHCR 
becomes involved only on the request of the UN. The UNHCR's Guiding Principles on Internal Displacement provides protections but is not legally binding on any party (Williams, p.511). It is categorized as a soft-law.

Both Williams and Castles examine the implications of a soft-law that would behave in ways similar to that of the UN Statement of Principles on the Internally Displaced. Since many climate refugees would remain within their state's borders, soft-law may have great appeal for policy makers. It would deliver a collaborative, non-binding, framework to establish a collective agreement on mutual understanding and common practices. It would mean that all concerned stakeholders would take a degree of responsibility with the applicable UN agencies facilitating the negotiations. One problem with an approach built on a non-binding framework is that it would provide little formal motivation for security or protection of potential climate refugees. Indeed, soft-law is considered by many to be inadequate to the task of protecting as many as 23 million IDPs, and as such is considered an inappropriate model for climate refugees.

The debates over how to address and define climate refugees will remain prominent in the years to come. Pressure on international organizations and the world's industrialized nations to resolve some of the most urgent issues is building. UN agencies, NGOs and the EU (which is already experiencing the pressure of environmental migrants moving into its southern states) (European Council, 2008) are readying their policy positions for discussion in Copenhagen in December 2009.

In 2009 , the two most important international refugee agencies appear to agree that the Convention should not be expanded. A recent Annual Report of the United Nations High Commissioner for Human Rights states that:

Persons forcibly displaced across borders for environmental reasons have been referred to as "climate refugees" or "environmental refugees". The Office of the United Nations 
High Commissioner for Refugees, the International Organization for Migration and other humanitarian organizations have advised that these terms have no legal basis in international refugee law and should be avoided in order not to undermine the international legal regime for the protection of refugees (UNHCR 2009b, p.20).

Given the different jurisdictional positions on climate refugees, and the difference in opinion among scholars, the next section will examine how Canada might fit within this international debate. It will consider the varied international influences on the historical evolution of Canada's refugee policy, along with the present state of debate about climate change and refugees in Canada, to consider the likelihood of Canada adjusting its refugee policy in the future.

\section{Canada}

Canada is an amenable partner with the UNHCR in its overseas refugee resettlement programs. Canada also supports the private sponsorship of refugees by Canadian citizens. It is generally regarded as a generous nation whose charitable values underlie its empathetic and compassionate refugee programs (Hamlin, 2009). In their study of Canadian electoral politics and the public's response to immigration issues, Black and Hicks (2008) found that Canadians believe that they are fair, especially when compared to the rest of the world. They are relatively confident that the number of refugees and asylum seekers accepted by their country on an annual basis is an adequate percentage of Canada's immigration intake and appropriate to the country's population size- - they are not necessarily willing to take more. For example, Li (2003) finds that Canadians are particularly concerned about increased numbers of 'visible minorities' (p.172-173).

Canadian refugee law and policy does not recognize environmental migrants, the largest number of whom will be racialized non-Europeans. But as the citizens of developed states come to understand the urgency of the plight of environmental refugees, Canada will be pressed by 
domestic and international actors to participate in the formal development of strategies that attempt to cope with migrants displaced by climate change. When that happens, the Canadian public will need to be assured that its government is acting in its best interests while keeping humanitarian and justice principles intact. What then has been the history of change to Canadian refugee policy and does it offer any guidance on factors that might drive change again?

\section{Background to UNHCR \& Canadian refugee policy: historic and comparative perspective to 1950}

The UNHCR was created to provide legal determinations for the passage of refugees with an emphasis on protection and resettlement. By the 1980 s it had begun to emphasize repatriation and now prioritizes repatriation and human security. Some charge that this emphasis comes at the expense of refugee protection and the right to asylum (Loescher 2001; Chimni 2000; Adelman 2001.)

Canada and Australia have had a fluctuating relationship with the UNHCR and its predecessors. I have identified seven key events that have particular relevance in Canada's history of response to refugees. This includes reflections on Australia, a comparative country, and the UNHCR. These historical events show how the relationship between Canada and the UNHCR has changed over time: 1) The Evian Conference, 1938; 2) 1951 Convention on the Status of Refugees; 3) Hungarian Uprising, 1956; 4) Canada Immigration Act 1976;

5) Vietnamese Boatpeople -1978-1980s, and Chinese Boatpeople - late 1990s; 6) Canada-US Safe Third Country agreement 2004/Australia's Pacific Solution 2007. These events demonstrate meaningful periods of convergence or divergence of policy among Canada, Australia and the UNHCR and provide context for the evolution of Canadian refugee determination. 
To conclude this section I will describe the growing move toward what can be described as the externalization of borders, interdiction and outsourcing by both Australia and the EU. Evidence indicates the beginnings of a similar trend in Canada. I will finish with a summary of the compromised authority of the UNHCR as it re-positions itself as the lead proponent of Human Security for refugees, displaced persons and asylum seekers.

\section{The UNHCR}

World War 1 flooded Europe with refugees displaced by the Russian Revolution and collapsed empires. They poured into a world that refused them any formal claim to refuge outside of their former homelands. Canada sent its officials to overseas ports in order to stop Europe's 'undesirables' from boarding ships bound for Canada (Dench \& Crepeau, 2003, p.2). In 1921, the League of Nations established The High Commissioner for Refugees (HCR) to deal with the refugees. Its first High Commissioner, Fridtjof Nansen, accomplished significantly more than was asked of him despite a limited three-year mandate supported only by voluntary donations from member nations (Barnett \& Finnemore, 2004).

The current international legal framework for the protection of refugees was born out of the chaos of the Second World War. Those horrors prompted the world powers to establish the United Nations in 1945 followed by the Universal Declaration of Human Rights in 1948. Article 13 of the Declaration declares every person's right to leave their country or to return, and Article 14 states, "Everyone has the right to seek and to enjoy in other countries asylum from persecution." Refugees displaced by war or the new political contours of their erstwhile homelands spilled into the countries of Western Europe. Some of them went further, to the new worlds of the US, Australia and Canada. 
The UNHCR was established for very practical reasons. European nations needed an agency that would take up the immediate responsibility of ensuring that refugees were repatriated or resettled. It was never intended to be an operational agency concerned with material matters such as supplies of food and shelter (Loescher, 2001). The US ran its own refugee agencies including the International Refugee Organization (IRO) and initially refused to support the new UN agency.

The first job of the UNHCR was to establish a legal framework for the protection of refugees which it accomplished with the 1951 Geneva Convention on the Status of Refugees. The strict terms of the Convention were grounded in ideology-it referred only to European refugees whose displacement occurred because of events occurring before 1951. Western European nations recognized the value of an ostensibly non-partisan agency that could represent their interests internationally and expedite the settlement of masses of displaced persons (Barnett \& Finnemore, 2004). As the industrialized nations aligned in opposition to the communist east, the UNHCR's resettlement of refugees from East to West lent legitimacy to the ideologies of the liberal democracies (Barnett \& Finnemore, 2004). Non-Europeans were explicitly excluded from the Convention.

Nansen, the first High Commissioner under the League of Nations, was a visionary who set the tone for future high commissioners of what would become the UNHCR. "Ambitious high commissioners seized on various crises and global developments to campaign for a broader mandate" (Barnett \& Finnemore, 2004, p.118). In spite of resistance from developed states which were not inclined to support action on behalf of non-Europeans, the UNHCR began a process by which it would become the expert authority on refugees from anywhere in the world. Most significantly, it also became the moral authority on refugees and refugee rights. 
The successes of the UNHCR provided a model of engagement with refugees from which Canada and Australia drew norms and policy. Their involvement with the UNHCR developed in stages; initially reluctant they eventually took pride in adopting the UNHCR's humanitarian principles with regard to refugees. Canada and Australia's participation in the international structure lent legitimacy to their newly emerged modern industrial democracies.

Australia acceded to the Convention in 1954, but it did not sign the 1967 Protocol until 1973. Up until then it had maintained a 'White Australia Policy,' established in 1901, which restricted nonwhite immigration. Canada became signatory to the 1951 Convention much later than the Western European nations in whose interest the UNHCR was established. It signed both the Convention and the Protocol in 1969 during a period of prosperity and economic growth. Like Australia, its traditional sources of immigration had dwindled, and an immediate need for labour meant it was ready to explore new immigrant resources. Prior to 1967, Canada's immigration policy also officially discriminated against non-white migrants. (Kelley \& Trebilcock, 1998). Hamlin (2009) suggests that the terms of the Convention and Protocol to which Australia and Canada acceded were very much an abstraction at the time. Had the countries been able to envisage today's refugee challenges, they might not have signed at all. The Convention committed both states to the non-refoulement of Convention refugees:

Signatory states have committed to determining whether a person is a refugee, and, if they are, to not sending them back to a place where they are likely to face certain types of persecution. In most circumstances, this commitment means that refugees acquire indirectly a right to remain in the state where they have claimed refugee status (Dauvergne, 2005, p.3)

Refugee flows in the decades before the Second World War demonstrate that the successive, small groups of bureaucrats who were responsible for Canada's ad hoc immigration 
and refugee policy held to their principal task-keeping racialized non-Europeans out. In 1914, 376 South Asians from India sailed into Vancouver's harbour aboard the Komagata Maru?. Abella (1993) captures the sentiment of the day with the words of a politician who warned that Canada should keep itself "pure and free from the taint of other people"10 (p.83). The bureaucrats established legislation that demanded all asylum seekers to Canada should come in a continuous journey from source to destination. The South Asians were denied entry since they had necessarily stopped on route. The continuous journey requirement was designed "to deter immigrants from Asia and other alien parts of the world" (Aiken, 1999, p.2). It foreshadowed the Safe Third Country agreement that would come into force some nine decades later.

In the 1920s, Armenians fleeing genocide were arbitrarily categorized as Asian and therefore deemed inadmissible according to Canadian policy (Kelley \& Trebilcock, 1998, p.202) An Immigration Branch bureaucrat declared that if Canada allowed them to enter, "our cities would be literally overrun with those unfortunates" (Abella, 1993, p.85). This was a direct snub to the authority of the High Commissioner for Refugees which had issued Nansen Passports to the Armenians and asked that countries accept people who carried the new refugee document.

In 1938 Canada participated in The Evian Conference on Refugees convened by the US to discuss the growing plight of Jewish refugees fleeing the widening Nazi regime. Canada argued against the creation of any international body that would be responsible for refugees and was adamantly opposed to the imposition of refugee quotas for receiving countries. Australia's position at the 1938 Evian Conference was much like that of Canada's. Its representative told the conference, "we have no racial problem [and] we are not desirous of importing one by encouraging any scheme of large-scale foreign migration" (Neumann, 2004, p.17). Despite this,

\footnotetext{
${ }^{9}$ The East Indians were not refugees. They were an organized group who sailed to Canada to challenge discriminatory legislation that kept East Indians from immigrating to Canada.

${ }^{10}$ This is a statement from Conservative Member of Parliament, H.H. Stevens.
} 
months later, Australia did agree to accept 15,000 Jewish refugees over three years on the basis that this would help to "greatly increase, particularly by the United States, the goodwill towards and prestige of Australia" (McMaster, 2001, p.42).

In 1939 another ship, carrying 907 Jewish refugees to Canada was turned back to Germany. Prime Minister McKenzie King warned that if the passengers of the St. Louis were allowed in they, and those who would follow them, would "'pollute' the Canadian bloodstream" (Abella, 1993, p.87). In the years preceding the war, Canada accepted only 4000 Jewish refugees (Abella, 1993, p.86).

In the years before World War 11 refugee acceptance in Canada was made on an ad hoc basis and through executive orders. Decisions were steered by bureaucrats who feared that foreigners threatened their insular societies-wartime interments were both politically and racially motivated. There was no refugee policy and no interest in drawing lessons from the nonsettler societies of distant Europe. Liberal Prime Minister Mackenzie King was led by public sentiment rather than any vision of justice. Canadians, whose ethnicities were overwhelmingly French and British with a small number of more recent settlers from Europe, felt that they had already contributed enough to the war (Kelley \& Trebilcock 1998; Inglis et al. 1994).

In 1939, only two per cent of Australians were neither indigenous nor Anglo-Celtic (Neumann, 2004). But Australia's response during the early years of the war was more generous than Canada's. It accepted around 10,000 Jews" , and its first public debate on resettling refugees was staged in those years. ${ }^{12}$ But it continued to prioritize matters of immigration. Prospective newcomers were assessed on the virtues of their potential contribution to the economy. The

\footnotetext{
11 Abella, (1998) argues that "Canada had by far the worst record in providing sanctuary to European Jewry" (p.86). 12 A proposal to settle 50,000 Jewish refugees (Neuman 2004).
} 
humanitarian aspect was secondary. The same motivations would maintain in Canada until well after the war.

In 1947, eight years after turning back the St. Louis, Canada finally allowed the entry of refugees who did not have relatives in Canada. Returning war veterans had brought back to Canada a new respect for the ethnic soldiers who'd fought alongside them as well as revulsion at the atrocities that had occurred in Europe based on notions of racial superiority. This combined with new pressure from domestic ethnic communities, who'd made their own contribution to the war, meant that the Canadian public was now more tolerant of a multi-ethnic society (Abella 1998; Kelley \& Trebilcock 1998). Despite this, refugees remained subject to criteria that were in Canada's self-interest. The Canadian Department of Labour's involvement in the selection process highlighted the priority of a refugee claimant's economic potential and social suitability. Communists and Jews were still routinely rejected. "An external affairs representative said that Canada "selected refugees "like good beef cattle" (Canadian Council for Refugees).

In 1948, Canada and Australia began to change their refugee regimes (Abella, 1993, p.89). British immigration to both countries had dwindled and it served them to relax their restrictive policies and adopt a more generous stance framed by the new post-war environment. In part, this was a response to international pressure exercised by Britain, the United Nations and the United States. But as well, an unanticipated post war boom meant a great need for more people and the first decade after the war saw massive immigration to Canada of a million and a quarter people, many from new source countries. That number included 100,000 displaced persons (DPs): “A new, more generous, more humanitarian policy towards refugees had captured Ottawa." (Abella, 1993, p.90). Australia competed with Canada and other New World countries for a hierarchy of desirable white European DPs. By 1953 it had resettled 180,000 refugees 
(Neumann, 2004, p.34).

\section{Refugee protection from 1950 to mid-70s}

In 1950, the initial work of the UNHCR emphasized the resettlement of refugees who were fleeing communism. This was an easy ideological fit for both Canada and Australia and was certainly the prime motivation for the acceptance of those refugees by the countries of Western Europe and the US.

In 1956 the UN asked the UNCHR to act as lead agency in the assistance of Hungarian refugees. The UNHCR first secured the blessing of member states including the US and was subsequently authorized by the UN to proceed. Although still constrained by the terms of the Convention that restricted it to refugee flows prior to 1951 , the UNHCR was able to act on behalf of the 200,000 Hungarian refugees because the antecedents of the Hungarian flight existed prior to 1951. The UNHCR also provided material assistance to the refugees, which established it as an operational agency (Loescher 2001; Barnett \& Finnemore 2004). In addition, it won the temporary right to designate the entire group of migrants as refugees in order to expedite the process. In this way it further escaped the constraints of the Convention which referred only to individual refugees and required case-by-case determinations. Barnett \& Finnemore (2004) argue that this pattern of innovation, capitalization, and subsequent approval was the dynamic that allowed for the growth of the UNHCR (p.86-87).

With respect to the Hungarian refugees, Canada and Australia were more than willing to respond to requests for help. The Hungarians were white, healthy, educated and skilled and the business community in Canada was enthusiastic. Canada, under the St. Laurent Liberals eventually selected 37,000 Hungarian refugees whose travel, along with their resettlement, 
education and training once inside the country was paid for by the government. Abella (1993) observes that this was probably the hallmark of Canada's new generosity toward refugees (p. 90). Around 14,000 Hungarians were resettled in Australia (McMaster, 2001, p.44).

In the 1950s the UNHCR evolved the Good Offices formula by which the UN General Assembly would grant the agency the authority to raise funds and to initiate assistance for refugee flows outside of its mandate (Loescher, 2001, p.36). Then, in 1957, the UNHCR received its first request for help from a Third World country, Tunisia, and again took the opportunity to continue to expand its mandate. By 1959 there were 200,000 Algerian refugees in Morocco and Tunisia. The UNHCR was able to identify the Algerian refugees as a group, as it had done with the Hungarians. And the UN allowed it to use its Good Offices to operate with a group that was outside of the Convention's European jurisdiction. The role of the Good Offices became very significant:

Perhaps the most important tool in the high commissioner's arsenal was the good offices concept. It gave him legal and political justification for action in 'contingencies and situations on the fringe of the normal activities of the High Commissioner's office,' allowing him to extend protection to new groups (Barnett \& Finnemore, 2004 p.92).

As the UNHCR garnered experience it developed its autonomy and authority to such a degree that it was able to pressure member states with regard to refugee activity in the rest of the world. The process of decolonization in the 1960s allowed the UNHCR to further expand its role. By 1965 it had abandoned the distinction between Good Offices and Statutory refugees and simply endeavored to protect all refugees. In turn, if Australia and Canada were to take their place among the leading developed nations and become participants in the international regime of refugee protection, they needed to be seen to subscribe to the new ideologies that were grounded in human rights and celebrated the spirit of decolonization. 
Post-Confederation, Canada's first mass non-European influx was in the early 1970 s. $^{13}$ The expulsion of Asians from Uganda put the British government under tremendous pressure and it asked Canada and other countries of the Dominion for help. According to Abella (1993), Canada was among the first to respond, and selected 6,000, the 'cream of the crop' who most closely met immigration criteria (p.92).

Despite increasing tolerance in Australia, welcome was not extended to Ugandan Asians. In response to the British Government's request, Australia's Prime Minister Whitlam, who despite being committed to ending the White Australia policy said of the Ugandan Asians, "if they've got qualifications such as entitle people to come to Australia, then certainly they can come"(Neumann, 2004, p.49). No special provision would be made to resettle the Asians on humanitarian grounds. Australia's reluctance was grounded in its exclusion of non-Europeans. In marked difference to the Canadian response, it issued just over 200 visas, although it did make an additional contribution to the UNHCR to help resettle the Asians (Neumann, 2004, p.48). By contrast, Canada's Liberal Prime Minister Trudeau, whose political vision articulated a Just Society, and "despite a worsening economic situation and a federal election in the offing... announced that Canada would accept some of the refugees" (Kelley \&Trebilcock, 1998, p.364).

Now Canada was providing lessons for Australia's policy makers to draw on. By 1973, Australia's White Australia policy was considered a 'dangerous anachronism,' and following much public and political pressure the government made discrimination based on race illegal (McMaster, 2001, p.140). Australia signed the 1967 Protocol, the UNHCR document that removed formal Convention limitations to non-Europeans, and following Canada's lead, began

\footnotetext{
13 Between 1820 and 1860 , around 30,000 black slaves came to Canada using the Underground Railway (Kelley \& Trebilcock, 1998)
} 
to move toward a multicultural policy (McMaster, 2001). The signing of the 1967 Protocol, seems to have come at a pivotal moment for both countries and signaled change to the world. Under the Trudeau government, Canada signed the Protocol in 1969 and Multiculturalism was implemented as policy in 1971 (Adelman, 1994, p.382).

In 1976 Trudeau's Liberal government implemented a new Immigration Act. It was designed to reflect widespread public input that included religious and community organizations as well as ethnic communities. This process created an Act that, for the first time, distinguished between refugees and immigrants. The new act recognized the humanitarian nature of the refugee response and established three separate categories by which refugees could be processed into Canada. ${ }^{14}$ One of these allowed for a designated class of refugees who could be helped by private Canadian Sponsors.

The evolution of Canada's response to refugees, particularly in comparison to Australia and in consideration of the role and influence of the UNHCR during this time, provides some important lessons or points of attention when considering the potential response to climate refugees today. The expansion of the UNHCR's mandate signaled to developed states that refugees in the Third World would receive the same protections as those from Europe. Its new mandate was sanctioned and funded by signatory states. Australia and Canada, now full participants with the developed states took their policy lessons from those states' relationships with the UNHCR. Canada affirmed its commitment to refugees in the 1976 Immigration Act, moving outside of the Convention definition to include 'displaced and persecuted' people who could be processed as part of a 'designated class.' Five years later Australia expanded its view of eligible refugees in its Global Special Humanitarian Program, which allowed it to accept "people

14 1) Apply overseas as a UN Convention refugee or as member of designated class (for private sponsorship); 2) Special measures for enhanced immigration access (individual cases); 3) Inland-refugee determination for convention refugees inside Canada (Kelley \& Trebilcock, 1998, p.405) 
who hold a fear of gross discrimination amounting to substantial violation of their human rights but not persecution" (McMaster, 2001, p.55). Now, both states had established the sort of policy that, in 2009 , would potentially allow them to accept environmental migrants.

Today, the UNHCR's influence has declined. Once able to capitalize on new refugee flows by expanding its authority, it appears to have retreated to a position from which it operationalizes refugee movements according to state interests. However, should environmental migrants create the chaos of uncontainable refugee flows such as occurred in the years following the two wars, states might once again ask the UNHCR to take responsibility for meeting the practical challenges and guiding the policy that helps states to justify their own response and practices on moral and humanitarian grounds. It will take multilateral action to cope with environmental migrants. In considering their potential policy positions in joining a multilateral response, Australia and Canada could draw on past policy lessons gained from processing the mass refugee flows of the Vietnamese boat people.

\section{Vietnamese boat people and the decline of UNHCR influence: mid-1970s to mid-1980s}

In 1978 a communist government was installed in Vietnam and large numbers of its citizens began to leave. This proved to be a pivotal period for the international refugee regime. Canada's response to the Vietnamese refugees, or "boat people" was exceptionally generous. The Conservative government of Prime Minister Joe Clark responded to wide, pro-Vietnam refugee media coverage and an outpouring of sympathetic public sentiment. Through the use of the private sponsorship programs established by the 1976 Act, Canada agreed to take as many as 50,000 refugees by 1980 (Abella 1993; Kelley \& Trebilcock 1998) 
Australia, recognizing that its economic interests lay in the Pacific Rim, relaxed its White Australia policy and began to accept Vietnamese refugees on the ideological basis that they were fleeing a communist regime, as well as for humanitarian reasons. Australians, too, were moved by the plight of the refugees and demanded a government response. (McMaster 2001; Watson 2006). As in Canada, family reunification programs meant that the Vietnamese continued to come throughout the 1980s, though both governments radically reduced their quotas as their countries fell into economic recession. Overtime, both Canada and Australia accepted about 137,000 Vietnamese each (UNHCR, 2000). But subsequent refugee flows, despite generous responses to certain refugee groups, would not receive the same welcome.

From the late 1970 s and into the 1980 s, Canada began to tighten its border controls. Asylum applications in both Canada and Australia were climbing: By the mid-1980s, the number of asylum seekers seeking refuge in the West had skyrocketed (Dench \& Crepeau 2003; Hamlin 2009). The increased financial cost of refugee flows overseas was reflected in increased requests to donor nations of the UNHCR for more help. As well, the already high cost of processing domestic asylum applications was also climbing: "Jet age refugees were no longer confined to their region of origin and now traveled directly to Western countries by air transport... The asylum crisis put Western governments into direct conflict with the UNHCR" (Loescher, 2001, p.41).

In Canada, a 1985 Charter of Rights and Freedoms legal challenge ${ }^{15}$ obliged the government to allow oral hearings for all refugee claimants. This caused a backlog of applicants which led to an administrative review program that amounted to a partial amnesty for claimants who could prove that they would be able to settle successfully in Canada. In 1986, the Canadian

${ }^{15}$ Singh v Minister of Employment and Immigration Canada 
people $^{16}$ were awarded the Nansen medal by the UNHCR in recognition of their generosity in extending that amnesty (Hamlin, 2009, p. 28).

The spirit of generosity did not last long. In 1987, a new boat arrival of 174 Sikhs off the Nova Scotia coast following a boatload of Sri Lankan Tamils in 1986 began a dramatic shift in public sentiment. A new backlog of claimants, and a series of domestic protests by ethnic groups in Canada reoriented the public and media discourse toward that of security. Following "tumultuous and acrimonious political and public debates," (Kelley \& Trebilcock, 1998, p.386) policy and legislation was designed to deal with asylum seekers who it was feared were drawn by the perceived welcome that Canada had conveyed to all asylum seekers with its amnesty (Hamlin, 2009, p.29). Bill C-55, which established the Immigration Review Board in 1988, also made provisions for Safe Third Country ${ }^{17}$ legislation whereby asylum seekers would be returned to the country through which they had traveled on their journey to asylum, so long as that country was signatory to international laws of protection. It would not be implemented, however, until 2004.

In the same period, Australia enacted new legislation that formalized limits to its refugee response. Canada began to impose visa restrictions on source countries. Refugee claimants traveling from the US were barred from entry pending a hearing date. By 1989 , under the Conservative government of Prime Minister Brian Mulroney, Bill C-84 allowed for the detention of asylum seekers until they had been proved credible by the authorities. Asylum seekers were now subject to immediate deportation (with judicial approval), and increased search and seizure provisions. Significant penalties were provided for people smugglers. In 1992, subsequent

\footnotetext{
${ }^{16}$ The only time a nation rather than an individual has received the award (Hamlin, 2008, p.12)

17 Modeled on the Dublin Convention in Europe that was designed to stop people making more asylum applications in more than one country (Hamlin, 2009, p. 32).
} 
legislation, Bill C-86, provided carrier sanctions, limits on rejected asylum seekers' right to appeal, fingerprinting and tightened entry interviews (Hamlin, 2009, p.31).

The Vietnamese boat people would prove to be the last mass influx to Canada. The doors were closing. While the Vietnamese remain perhaps the foremost contemporary success story of the absorption of non-European refugees into Canadian and Australian societies, they marked the end of an era for the UNHCR (Barnett \& Finnemore, 2004). The refusal of neighbouring Southeast Asian states to give the Vietnamese refuge was exemplary of a growing discomfort in the developing world. Developing nations that struggled with the political implications of absorbing their neighbours' displaced populations, as well as the environmental and social pressures of refugee movements, made increasing conditional demands on the UNHCR, NGOs, and developed states to support them in their efforts to provide refuge (Barnett \& Finnemore, 2004, p.95).

Two concepts left behind from the Indochinese experience-international burden-sharing and temporary asylum-'proved a mixed legacy, both capable of being applied either to great humanitarian advantage or as an easy excuse to shift the responsibility and avoid the blame ${ }^{18}$ (UNHCR, 2000, p.102)

Developed states no longer saw resettlement as a durable solution. Donations to the UNHCR, on which it depended, were not keeping pace with its spiraling costs. In the 1980 s the UNHCR began to de-emphasize protection and to address the root causes of flight and the potential for repatriation (Barnett \& Finnemore 2004; Loescher 2001). Over the next few years budgetary problems led to increased scrutiny of the UNHCR's budgets by the UN and concluded in 1989 with a decision to cut the UNHCR's staff by 15 per cent and its programs by 25 per cent. From enjoying years of relative independence and the ability to set its own agenda, the UNHCR

${ }^{18}$ Quote from A. Simmance, 'The International Response to the Indo-Chinese Refugee Crisis', paper presented at international seminar on the Indochinese Exodus and the International Response, Tokyo, Japan, 27-28 Oct. 1995. 
was effectively brought to heel by its Executive Committee, which in turn was steered by affluent member states. According to Barnett and Finnemore (2004), "[W]hile in the 1970s UNHCR seemed able to confront and work with governments simultaneously, during the 1980s its relationship became more adversarial and it worried that it was angering the very states on whom it was dependent to sustain its activities" (p.95).

Affluent states had reached their perceived financial, political and social limits: They told the UNHCR it must put a stop to the increasing numbers of asylum seekers to developed states whom they charged were often economic migrants. Protection, and overseas resettlement, should cease to be a primary concern. Asylum seekers should be kept within their regions and returned to their homelands as quickly as possible.

While states debated the virtues of repatriation, the UNHCR's own repatriation discourse evolved far away from Canada and Australia. The UNHCR was under increasing pressure from Bangladesh to send 250,000 Royangan refugees back to Burma. In the mid-1990s, the UNHCR began (with a degree of coercion from the Bangladeshi government) to suggest that the Royangas would be better off back in Burma. This was the beginning of the shifts in discourse that allowed for what some have alleged was the sometimes involuntary return of Royangans. The UNHCR had moved its focus from exilic resettlement to repatriation; it had taken a narrow interpretation of the convention, which was entirely at odds with its previously expansionary view. It also claimed that it was able to successfully operationalize and monitor the circumstances of repatriation.

States were...rolling up the welcome mat and demanding that refugees go home as soon as possible. But UNHCR staff also had independently determined that it was time to overcome its exilic bias and to help an increasing number of refugees who wanted to go home" (Barnett \& Finnemore, 2004, p.119) 
The discourse from this time forward would be one of justifiable repatriation. This supported states' notions that asylum seekers had less right to remain in developed countries. According to the UNHCR, only 14 per cent of the world's refugees make it out of their own region. Most of these go to neighbouring states. The UNHCR asks all settlement countries combined, including Canada, to take less than one per cent of the world's refugees. In effect, less than one per cent of the current UNHCR refugee number of 15.2 million ${ }^{19}$ is shared between about 19 countries that have official resettlement programs. In 2008 the UNHCR asked states to consider 121,000 refugees for resettlement. Of those, 67,000 refugees were resettled. Overall, 88,000 refugees (UNHCR recommended and otherwise) were resettled in 2008. Of these, the US accepted 60,200 (Global Trends 2008). Australia and Canada annually vie for second place. A degree of Canada's international reputation relates to the influence of the Charter of Rights and Freedoms. It established a standard of justice that was extended to refugees and won Canada international commendations. But Canadians quickly became concerned that too many potential asylum seekers viewed entry to Canada as easy. Those concerns coalesced in a vigorous antipathy toward new boat arrivals. Fears about 'opening the floodgates' dominated the discourse.

In its response to the Vietnamese boat people, Canada focused on orderly processes for refugee selection from overseas under the jurisdiction of the UNHCR. Government supported public sponsorships meant that large numbers of Canadians had a stake in the success of the refugee intake. Public and media support played a principal role. This experience suggests that should the Canadian government be able to show that it can control the processing of environmental migrants in an orderly fashion, despite their potential numbers, it could calm the

\footnotetext{
${ }^{19}$ In 2008 , there were 42 million forcibly displaced people in the world, including 15.2 million refugees; 827,000
} asylum-seekers; 26 million IDPs. (2008 Global Trends, UNHCR) 
public's fear of being overwhelmed.

\section{Boat invasions: security as the new refugee policy norm}

Thanks to smugglers, countless people escaped Nazi Germany, Franco's Spain, Vichy France, Central Europe during the Cold War, Vietnam in the 1970s, Guatemala in the 1980 s, and many other abusive regimes. The repression of migrant smuggling as it is intended to function today would not have allowed them to find protection elsewhere (Dench \& Crepeau, 2003, p.3).

At the end of the 1990s, a few boatloads of Chinese migrants totaling 599 people arrived on Canada's West Coast seeking asylum. The ensuing debate, played out in the media and exploited by politicians, was volatile. Once again, public sentiment steered the government response, but this time to a markedly different conclusion than was reached for the Vietnamese Boat People. Hamlin (2009) observes that media coverage in both Canada and Australia often peaks when asylum seekers arrive by boat, and may be followed by restrictive legislation.

The Chinese were incarcerated and speedily processed. Jean Chretien's Liberal government politicized the immigration debate by focusing on its human smuggling aspect and charged that the Chinese were abusing Canadian generosity (Hamlin 2006; Li 2003). Meanwhile, Canadians engaged in a tug-of-war of values - a national opinion poll showed that 50 per cent of Canadians wanted the boatpeople to be processed as refugees while the other 50 per cent wanted them removed. Finally, all but 16 were deported (Li, 2003, p.182).

Canada's refugee welcome has remained cool since the late 1990s. This is evidenced by the provisions of the 2002 Immigration and Refugee Protection Act that was debated and designed during the same period as the Chinese deportations. The contentious safe third country legislation, first proposed in the late 1980s, was implemented in 2004. While some have suggested that Canada's ambivalence or reluctance toward refugee acceptance is in part a response to attacks in the United States by foreigners in September 2001, Whitaker (2002) 
argues that Canada's 2002 Act, debated before the attacks, had already done a great deal to curtail non-citizen rights on grounds of security. Interests of national security now trumped humanitarian concerns.

In 1999, while Canadians were debating the treatment of boat arrivals on their west coast, the Australians were facing a new boat 'threat' in the form of smuggled asylum seekers from Afghanistan, Iraq and Iran (Hamlin, 2008, p.40). The majority of them were recognized as bona fide refugees by the Australian courts but were nevertheless issued only temporary visas. In 2001, Australia's hostile response to repeated boatloads of asylum seekers culminated in its refusal to allow entry to a Norwegian ship, the Tampa, which had rescued 438 Middle Eastern refugees from a sinking ship just outside of Australian jurisdiction. Despite the negative international attention that the Tampa incident received, public opinion supported Prime Minister Howard's position.

A subsequent number of restrictive legislations were enacted by Australia in 2001. What would be called the 'Pacific Solution' ${ }^{20}$ included provisions for interdiction at sea; an agreement with Indonesia to prevent smugglers and boats from leaving their shores for Australia; the removal of Australia's responsibility to process asylum seekers by excising more than 4,000 islands from the Australian migration zone. ${ }^{21}$ It also relocated a number of detention centers to offshore locations that were outside of Australian law. In return for millions of aid dollars, the sovereign island of Nauru became host to detained asylum seekers in camps that were administered by the UNHCR and the IOM (Hamlin, 2009, p. 42) "States increasingly view

\footnotetext{
${ }^{20}$ The Pacific Solution was removed as policy in 2007 by a new government. But the legislation remains in place. (Hamlin, 2009, p.45)

21 A non-citizen needs a visa to legally enter and remain in the migration zone which includes states, mainland territories and extraterritorial territories at water line. Excised islands include Christmas Island which houses a major detention center.
} 
refugee rights and non-refoulement as inconvenient obstacles when they have decided that it is time for refugees to go home" (Barnett \& Finnemore, 2004, p.75).

The UNHCR played a significant role in the Pacific Solution. In hand with the IOM it processed asylum seekers in third countries such as Nauru and Papua New Guinea, effectively on behalf of Australia which had circumvented the 1951 Convention by avoiding its obligation to process asylum claims on its soil. Watson $(2006)^{22}$ contends that along with increasing its donations to the UNHCR, Australia emphasized the UNHCR's assistance to the third countries that now processed Australia's asylum seekers. Watson (2006) argues that Australia's refugee humanitarianism is now characterized by, "refugee resettlement and non-violation of international obligations" (p.13). Developed states may take their lessons from Australia: The number of asylum seekers who reached its borders dropped by 75 per cent between 2000 and 2005 (UNHCR, 2006).

It is in this recent era, characterized by security and containment, that the debate over environmental migrants has become more prominent. While scholars and refugee advocates have long recognized the implications of climate change in refugee generating events, the UNHCR and the developed states have only recently taken up the debate. The last two decades have seen the reorientation of refugee protections. It is unlikely that environmental migrants will receive any specific recognition until their condition becomes so urgent that it can no longer be avoided.

The emerging and shifting discourse of states that portrays refugee migrations as political matters of national security is evolving at the same time as the UNHCR's attempt to maintain state support for refugee protections with the discursive reframing of protection as "human security.'

22 From a paper presented by Scott Watson in 2006 (see references). Cited with permission . 


\section{The National/Human Security discourse}

The initial emphasis of the UNHCR was exilic. By the time the Cold War was over, it had shifted its emphasis to one of repatriation. Joly (2001) traces the course of the UNHCR from its inception as an agency whose international support was based largely on its function in managing the asylum seekers of the Cold War. That international support is waning. Joly (2001) points to the growing primacy of developed states' domestic policies in recent years, charging that they are steered by an "overbearing neo-liberal economic model" (p.13). In the mid-1980s, states began to close their borders and a new era of repatriation was begun.

In 1992, the UNHCR referred to human security but emphasized asylum and protection. By 1994 it was emphasizing repatriation. Adelman (2001) shows that by 2001 the emphasis had changed again: "Protection of refugees was now being defined as the security of refugees" (p.7). The UNHCR recognized that refugee populations have the potential to unbalance either their own states' or their host state's economic, social and environmental stability, thereby compromising political security (Adelman 2001; Loescher 2001). This, in turn, threatens the security of the refugees themselves, as well as the citizens of the receiving nation. The very security of humanitarian operations and their workers, including UNHCR staff, was also under threat. States now prioritize national security and the UNHCR complements their discourse with its emphasis on human security. "Uprooted populations", 'displaced people' and, 'involuntary migrants' are new terms which tend to replace the concept of refugee; this slippage in the terminology is indicative of UNHCR's response to the new demands of its member states" (Joly, 2001, p.12). 
For the developed states this has meant regional cooperation on migration controls including interdiction and detention. There is also a growing trend toward harmonization of containment measures, both regionally and internationally. Both the EU and Australia have devised containment policy. The security dimension of these practices allows government agents to justify a degree of secrecy. Much of the work of interception takes place outside of the destination country so is kept from public view. Brower and Kumin (2003) contend that many of the regional and intra-regional meetings focused on interdiction and detention take place behind closed doors (p.12). Canada is a party to the Puebla Process, a Regional Conference on Migration to which the US, Central American States and Mexico also contribute. In 2002, Canada participated in a workshop on interception held by The Inter-governmental Consultations on Asylum, Refugees and Migration Policies in Europe, North America and Australia (IGC). These are examples of a growing list of Regional Consultative Processes (RCPs) which are neither well recognized, nor debated. It is at such meetings that Canada and other states determine migration objectives (Brower \& Kumin, 2003). For example, one of the Pueblo Process 2002 objectives was the "promotion of better understanding to enhance public awareness of the harmful effects of migrant smuggling and trafficking in persons" (p.3).

In the 2000 s, the developed nations of the world have containment as an early objective. The world has yet to face rapidly increasing numbers of environmental migrants, but at present it seems that the effort will be to contain them within their regions and the infrastructure to do so is becoming more sophisticated. "A new discourse carefully chisels an ethical and ideological foundation to the new regime" (Joly, 2001, p.3). Humanitarianism is central to the new discourse. 
Today's exclusionary refugee regime is carried out despite states' continuing commitment to the terms of the 1951 Convention. All states that are signatory to the Convention continue to recognize the right of refugees to non-refoulement. Current measures are not articulated as exclusionary and are very often conducted out of the public view. This is likely to continue until such time as international agencies, such as the UN-and/or a collective of developing states - publicly and forcibly challenges this dominant and emerging regime. Until then, when forced migrations occur, humanitarian operations led by the UNHCR and the IOM will endeavor to keep refugees within the confines of their state. If asylum seekers cross borders they will be kept within their region and contained in neighbouring states. Funding for their stay will be processed through the UNHCR and the IOM. If they try to leave by plane they will need visas that prove impossible to obtain. If they leave by boat they will face consequences that may include interdiction by state authorities. (For example, a rare, documented case in 1999 revealed the complicity of an IOM official with the Canadian government in the forced 'voluntary' repatriation of a boatload of Sri Lankan Tamils) (Cheran 1999; Aiken 1999). Asylum seekers may die at sea since smugglers and traffickers have responded to the universal crackdown by putting their clients in boats that are un-seaworthy (so reducing the smuggler's material and financial risk - indeed, some asylum seekers are sent to sea in inflatable boats that they are responsible for sailing themselves) (Cheran, 2009).

The asylum seekers who do reach destinations in the developed states face the increased possibility of detention, sometimes in isolated, offshore locations. The UNHCR does not publish a list of all of the detention centers in all of the states (Marfleet, p.266). Asylum seekers might find their applications 'fast tracked' (often leading to repatriation). If they do stay they may 
receive very little social support, or their protection will hinge on a temporary visa that can mean their status in country remains precarious, paving the way for a host of social problems.

Asylum applications to the developed countries rose from 200,000 in the early 1980 s, to a record high of 850,000 in 1992, then dropped. Numbers peaked again in 2001 at 600,000 (Hatton, 2009, p.1). Over those years, 68 percent of the asylum applications were made in the countries of the European Union. Overall, between 1987 and 2006, Australia has experienced a 61.7 percent decline in asylum applications, and Canada was down 8.6 percent. In the EU countries the trends are extremely diverse. For example, applications to the Netherlands decreased by more than 60 percent while France experienced an increase of more than 50 percent. While the EU moves steadily toward harmonization, Australia's technique of interdiction and detention has clearly proved very successful.

In 1996, the Canadian Immigration Minister established a panel to explore how best to prevent immigrants from defrauding the system (Hamlin, 2009, p.14). Canada, like other states was moving its interdiction and interception tactics beyond its own borders in order to escape the obligations of the 1951 Convention. The Canada Immigration and Citizenship's (CIC) Intelligence Branch established an international network of Migration Integrity Officers who work in the airports and seaports of the countries most likely to generate asylum seekers. Those officers coach private agents such as airport staff to screen passenger documents. The CIC reports that at least 40,000 people were successfully interdicted while on route to Canada between 1996 and late 2002 under a Liberal government (CIC Factsheet 2002). According to Brower \& Kumin (2003), Migration Officers "do not appear to have any mandate to examine the intercepted person's motivation for migration or to address any need for international protection" (p.10). In effect, they may be guilty of refoulement according to the Convention. As Marfleet 
argues, "Today's refugee becomes tomorrow's bogus asylum seeker" (p.10).

A Convention refugee is distinct from all others who are displaced because she or he is able to meet the limiting criteria of the definition. Environmental migrants are among those who are excluded from this group. As Dauvergne observes, the designation, "refugee" is not based on need. The starved and the destitute do not necessarily qualify" (p. 618). Marfleet shows that states' increasingly narrow interpretations of the Convention mean that the distinction between refugee and migrant has blurred. Today, "those who apply for asylum in the West are routinely assumed to be illegitimate" (p.12).

Human rights NGOs, along with refugee advocates are now working hard to have the plight of environmental migrants included in the Copenhagen discussions of the Conference of Parties to the United Nations Framework Convention on Climate Change (UNFCCC) in December 2009-a meeting intended to establish a post-Kyoto climate regime. They will no doubt make demands upon the publicly stated, humanitarian positions of the world's developed states. But Canada, Australia and the EU have all used humanitarianism as a justification for keeping asylum seekers away from their borders. This is based on the preeminent and humanitarian necessity of protecting the social stability and safety of their citizens, and stopping the activities of 'people traffickers' who endanger the lives of the migrants that use them.

Watson (2006) argues that "a state centric vision of humanitarianism" has developed that employs "legitimizing thetoric" to place state security above individual protection.

"Humanitarianism [has become] dependent on the maintenance of state security" (Watson, 2006, p.2). Canada, like other neo-liberal, developed states, embodies humanitarianism as one of its core principles. Chimni (2000) argues that this "new humanitarianism" is used to justify the exclusion of certain immigrants, refugees and asylum seekers. “'Humanitarianism is the ideology 
of hegemonic states in the era of globalization marked by the end of the Cold War and a growing North-South divide" (Chimni, 2000, p.244).

Exploitation of the world's resources, including its people, has resulted in growing inequities between North and South that are exacerbated by neo-liberal ideologies which allow global capital to be steered according to the imperatives of capitalism (Chimni 2000; Marfleet 2006; Dauvergne 2005). Much human migration is a result of exploitation that is rooted in colonialism and now plays out in post-colonial, political-socio-economic relationships.

While most migration is regional in nature, a much lesser degree does occur from South to North. Some migrants exist in the shadow land of the undocumented and the illegal. Others arrive at the borders of affluent northern nations as immigrants, refugees, or asylum seekers. If notions of humanitarianism and justice frame the debate over how many migrants should be allowed access, Dauvergne (1999) shows that there is no consensus that articulates a 'just' number. Since there is no agreement on what is 'just' there is therefore no baseline against which laws, regulations and norms can be judged. Without a consensus agreement, Dauvergne (1999) argues that decisions are not guided by morality, but take place in an 'amoral realm.' What is just and moral for those whose privilege is to remain, by choice, within the borders of their affluent state, is not just or moral for those who are excluded.

Sovereignty is premised upon the legitimate authority to control borders in order to protect the interests of those who have legal status within them. Benign humanitarianism is the motivation that, from time to time, opens those borders. According to Watson (2006), states have fostered humanitarianism in their citizens and this has paved the way for formal refugee resettlement in states such as Canada (p.5). But scholars argue that once humanitarianism has been internalized and normalized as part of a state's identity, it can also become securitized. This 
leads to justifications of exclusion on the basis of humanitarianism (Watson 2006; Dauvergne 1999; Chimni 2000).

Humanitarianism, like 'just' quota, is not defined in international law, so does not oblige those who claim to subscribe to its principles to behave in any particular way (Chimni 2000). Internal domestic standards of liberal, sovereign justice, and the principle of humanitarianism, are consequently of little value to those who seek entry, but at the same time, are the only thing that asylum seekers can depend upon. All refugees and asylum seekers must count on a perceived humanitarianism that transcends politics, sovereign interests and public sentiment. Instead, Nessel (2009) shows that forced migrants find themselves "floating between a humanitarian-based international protection regime and a restrictionist immigration regime" (p.654).

States lean heavily on past "humanitarian" actions, such as previous rates of refugee acceptance, while employing a discourse that re-defines asylum seekers and refugees as economic migrants, cue jumpers, illegals, gate crashers, undocumented. Once re-named, forced migrants are subject to a variety of strategies that thwart their entry, or criminalize them once they have entered. This security-oriented concept of humanitarianism does not hold out a great deal of optimism for the potential recognition and protection of environmental migrants.

\section{Environmental migrants: contemporary discourse in Canada, Australia, and the EU}

The historical development of refugee law and policy has evolved based on 'geopolitical considerations' rather than humanitarian principles. According to Williams (2008), the geopolitical nature of environmental migrant flows is now apparent to many developing 
countries and organizations such as the UNHCR, but has not yet been afforded 'political priority' by the developed states (p.509).

Canada lags far behind many other developed states in developing a position on environmental migrants. An exploration of the evolving positions of developed states is useful, since in the absence of moral and expert leadership from the UNHCR it is from these that Canada is likely to draw its lessons.

In Canada, environmental refugees are so far removed from any public or political discourse that they seem not to exist. A search of the major Canadian media finds less than twenty references to climate refugees, or environmental migrants in the last two years. Of these, four are in connection with book reviews. All but two are delivered in a playful tone that suggests the references should be considered far-fetched, in the same realm as doomsday scenarios. Two are based on climate change denial ${ }^{23}$ and two are coverage of speeches by US President Obama. Peter Penz, a refugee scholar from York University, and Gwynne Dyer, a respected historian and journalist received a smattering of attention, often focused on the more sensational aspects of their statements on climate refugees. The $\mathrm{CBC}$ has run four or five stories a year that reference environmental migrants. The major NGOs such as Greenpeace, The Suzuki Foundation and Amnesty International make only cursory references to climate change refugees. None of them advocates on their behalf.

Of Canada's four political parties, only the Green Party makes a reference to environmental refugees in its platform or policy statement. Taking its figure of 200 million refugees from the Stern report the Green Party's platform states:

Our immigration policies must be revamped to ensure we stay true to our identity as a just, fair and open country, and to be prepared for new challenges that are predicted to

${ }^{23}$ See references for Ebell (2009) "Obama's climate fantasies," and Solomon (2009) "High risks in climate change policy." 
arise with increased numbers of environmental refugees seeking a safe new home in an increasingly perilous world (Green Party Program, 2009)

This statement fails to articulate either a time frame or a level of response, rendering it weak and ineffectual. The governing Conservative party has thus far failed to formalize its international position on the mitigation of climate change effects. Environmental refugees are very far from its stated concerns. It is, however, currently engaged in a discursive reframing of immigration and refugee policies. Prime Minister Stephen Harper has called Canada's immigration system, 'broken,' thereby justifying the imposition of visa requirements on two additional refugee generating countries. CIC reports that the number of asylum seekers accepted to Canada has plummeted in the last few years: a drop of 56 per cent in the three years between 2005 and 2008 (Curry, 2009). During the same period the number of people allowed into Canada as temporary workers, a strategic, economic category, jumped from 90,000 to 192,000 (Swan, 2009). Canadians guard and maintain their enormous privilege. An opinion poll conducted in July 2009 found that 56 per cent of Canadians felt that the refugee determination system should be changed to make it more difficult for people to make "false claims" (Angus Reid, 2009).

While Australia's interdiction practices are wide reaching and have been very successful, the new Rudd government ${ }^{24}$ has acted to remove some of the more contentious practices while keeping the past government's legislation intact (Hamlin, 2009). It has so far failed to signal that it might recognize environmental migrants. In August 2009, Australia announced a new policy to support pacific islanders who continue to abandon their villages and farmland to rising waters. Prime Minister Rudd said Australia would help with the internal relocation of refugees on the islands.

24 Prime Minister Kevin Rudd's Labor government was voted into office in 2007. John Howard's Liberals governed from 1996 to 2007 
Tuvalu is one of the pacific islands off the coast of Australia that may well be submerged by the sea in the next few decades. Many islanders have already given up their lands to the sea and migrated to New Zealand. While New Zealand has a Pacific Access Category (PAC) agreement with Tuvalu that allows immigration quotas for the pacific islands, critics argue that given its emphasis on labour qualifications it is more concerned with economics than with environmental migrants (Williams, 2008, p.515). Initial response to the PAC by refugee advocates was enthusiastic since it seemed to offer some hope of formal recognition to environmental migrants. However, Hoadley (2003) argues that Australia's concerns about migrants using New Zealand as a stepping stone to Australia's social security system led to the trans-Tasman compromise which resulted in a near convergence of Australian and New Zealand immigration and refugee policies (Hoadley, 2003).

In October, the Australian Green Party called for a new visa category for climate change refugees, and Australian lawyers are promoting a Convention for People Displaced by Climate Change (Nelson, 2009). Meanwhile, a government MP has warned Australians that if they don't populate Australia's underdeveloped north, they will "face invasion by Asian refugees driven south by climate change" (Squires, 2009).

The states most immediately at threat of climate change sea level rises are lobbying vigorously for action. Tuvalu's prime minister ${ }^{25}$ says his people don't want to be treated as refugees-they are being trained to be able to take jobs and will be ready to fit in (Now, 2008). The president of the Maldives warns that his people face the prospect of life in a "climate refugee camp" (The Daily Star, 2009). Bangladesh's finance minister ${ }^{26}$ has asked the world's industrialized countries to take millions of climate refugees. He is supported by the chairman of

${ }^{25}$ President Tong wants other countries to train his people for the jobs that they will need when they migrate.

${ }^{26}$ Abul Maal Abdul Muhith. He also called on the UN to open the refugee Convention to include climate refugees (Grant et al.). 
the IPCC who says that developed world will need to take "legislative action" in order to process and settle up to 40 million people (Grant et al, 2009).

The EU's geographical relationship to the countries of Africa is similar to that of Australia's to the Pacific Islands and Asia. It is an obvious destination. In the absence of policy from the US, the EU will arguably have the greatest influence on the international refugee regime as it attempts to form a position on environmental migrants. While there is a differential response among many member states, the formal EU bodies are tackling the issue. In 2007, the Belgian government voted in a bill asking the Belgian delegation at the United Nations to promote international recognition of environmental refugee status (Chope, 2009). In 2008, The European Parliament adopted a declaration to "organize legal protection for the victims of climate events" (Chhabara, 2009). And in 2009, the Council of Europe stated that "the protection of people compelled to move due to climate and environmental factors is of paramount importance" (Chope, 2009).

Does the existence of national and international debate on climate refugees signal that there is a potential for change in Canada? In 2009 , the Canadian public is racially and ethnically diverse. Globalization and transnationalism have created complex social, political and economic international relationships. If the UNHCR is able to communicate a vision of a world in which the suffering of environmental migrants can be redressed, Canada, Australia and other developed states might be convinced to fund and participate in international programs. If the EU and the UNHCR agree on a designation for environmental migrants which obliges EU member states to engage in proactive and protective measures on their behalf, Canada might find pressure from political allies and trading partners, coupled with the concern of Canadian citizens about their 
former fellow nationals, difficult to resist. Canada would be able to draw its policy lessons from those formulated by the EU.

In 2009 , however, there is very little to suggest a change is in store. The extremely low level of domestic public debate about climate refugees, the increasingly security oriented internal and external immigration and refugee discourse and apparatus are not encouraging. These, along with Canada's persistent reluctance to take any action on climate change, are poor signals that Canada might soon be a leader in responding to climate refugees.

\section{Looking ahead: Canada's prospect for change}

In 2009, the question of what policy Canada might develop in response to environmental migrants is characterized by a gamut of unknowns. These persist because no developed state or international agency has committed to formulating rights and protections for environmental refugees. Canada has not even begun to address the issue. Other unknowns have been absent from the discussion presented in this paper, such as the degree of influence the US may have on Canadian refugee policy once it determines its own policy on environmental migrants. The US is the world's foremost refugee resettlement state, and the most desirable destination for asylum seekers. In the absence of policy from any developed state I have attempted to show the policy paths Canada may choose from by studying its historical record, reviewing the current trajectory of the international refugee regime, and revealing the nature of the developed world's humanitarian response.

The debate over providing formal status for environmental refugees was begun in the early 1980s. Nearly thirty years later it is unresolved, although one avenue appears to be closed. In 2009, The United Nations and the UNHCR have recently stated that expansion of the 
Convention definition is neither desirable nor plausible. And developed states that are already dealing with asylum seekers whose migrations are explicitly linked to climate change have so far refused to recognize that link to those migrations.

There now appears to be a high level of convergence in refugee policy between Australia, the EU, and to a lesser extent, Canada. All have engaged in systematic efforts to secure their state's borders against asylum seekers and to contain refugee flows at their origin. Dauvergne (2005) argues that the various ways in which these jurisdictions circumvent refugee law shows that they continue to accept that they have an international obligation to refugee protection or they would have simply abandoned it altogether. They are, however, engaged in a "race to the bottom to harmonize refugee law" (p.19).

In the meantime, a discourse of denial is carried out within which developed states may frame their refusal to act. A World Bank working paper (Raleigh, 2008) analyzes the claims of those who posit massive climate migrations and summarizes, "We examine evidence for such claims and roundly conclude that large scale community relocation due to either chronic or sudden [climate] onset hazards is and continues to be an unlikely response" (p. iv).

An examination of Canada's past history of refugee reception reveals a marked shift over time from explicitly discriminatory policies to policies that are founded on non-discriminatory language. It has maintained its obligations to the Refugee Convention, at times with real generosity. Today, despite the primacy of security, it continues to uphold those obligations. However, history also reveals a degree of sophistry on the part of Canadian politicians and officials. This occurs regardless of political affiliation. ${ }^{27}$

Canada's lack of commitment to Kyoto objectives, its absence from the debate on

\footnotetext{
${ }^{27}$ Canada has never seen the development of an anti-immigration political party of the sort that characterizes politics in some European states.
} 
environmental refugees, its prioritizing of neo-liberal economic goals, its shared place in the hegemony of globalization and the new humanitarianism, would suggest that it will not change its refugee policy to recognize any special status for people whose forced migration and permanent displacement is directly linked to climate change. Given the foregoing contextualization, Canada may choose to draw its policy lessons from Australia, the state whose overseas refugee selection process most closely mirrors its own. If so, policy will be revised to effectively eliminate the right of migrants to claim refugee status in Canadian jurisdictions. Canada, however, would risk its international reputation-certainly among developing nationsfor taking such a position and would no doubt be admonished by the UNHCR with whom it has had a successful relationship for decades.

Canada's current Conservative government has managed a 56 per cent drop in asylum acceptance rates, and is in the process of a discursive reframing of Canada's refugee regime. It has called the refugee determination system broken and allowed a backlog of claims that (perhaps) will eventually need to be addressed with emergency measures. No formal exclusionary policy has been announced. Harper's government will be aware that Australia's Hawke government collapsed in part because of extreme formal and informal ${ }^{28}$ measures it used against asylum seekers.

However, Canada has also shown itself to be capable of solid leadership in the international refugee regime, expanding its interpretation of the Convention to include gender persecution, and recently considering the refugee claims of American war resisters. The Canadian public is generous, and its uninhabited or under-inhabited land mass is vast. Canada could become a leading participant in ongoing negotiations toward a new framework for

\footnotetext{
${ }^{28}$ The Hawke government accused asylum seekers of throwing their children overboard in order to be rescued. This accusation proved to be a lie, and led, in part, to the defeat of the Hawke government in 2007 (Hamlin, 2009, p.45).
} 
environmental migrants. In the lead up to the 2009 Copenhagen conference the UNHCR has asked that states focus on international cooperation and human rights as they consider environmental migrants, since "it may take some time to reach agreement on the appropriate way forward" (UNHCR, 2009a, p.9). The report suggests that one way forward may be with a new legal framework.

By drawing from the eventual policy recommendations of the UNHCR and the bodies that advise the EU parliament, Canada could establish a set of criteria to ensure that environmental migrants overseas are relocated to viable land and receive adequate assistance from the international community to make those lands sustainable. It could advocate for the human rights of environmental migrants in the international arena and it could establish a quota of environmental migrant acceptance to Canada, expanding its refugee determination system to accommodate the new category. In Canada's case this would not require major domestic policy changes. It would need only to expand its current recognition of "country of asylum class," or "source country class" programs ${ }^{29}$ to include countries that produce environmental migrants. Sudan, an environmental migrant producing country is already a "source country."

The potential number of environmental migrants, however, overwhelms imagination, and politicians would need to reassure Canadians that their own personal socio-economic securities would be maintained even while they are meeting the challenges of a new carbon reduced economy. History shows that governments are able to coach the media and steer public opinion. The government would need to increase spending on resettlement programs, possible locating refugees in regions that are now under populated. This is contentious ground, and might well meet resistance from refugee advocates, but the extreme nature of the intake might be seen as

\footnotetext{
${ }^{29}$ The CIC has established these classes for non-Convention refugees. The source country class requires private sponsorship from inside Canada. See: http:/www.cic.gc.ca/english/refugees/outside/index.asp
} 
justifying the method. The government would be able to draw on a wealth of current knowledge from refugee and immigration scholars, settlement agencies and urban planning and community development experts. History shows that that Canada has capitalized, to its great advantage, on past refugee flows. It could choose to do so again while simultaneously emerging as a global leader in response to the impending increase in populations displaced by climate-induced change. 


\section{References}

Abella, I. (1993). Canadian Refugee Policy to 1980. In V. Robinson (Ed.), The International Refugee Crisis: Canadian and British Responses. (pp.77-94). London: Macmillan

Adelman, H. (1994). Justice, Immigration and Refugees. In H. Adelman, A. Borowski, M. Burstein, L. Foster (Eds.), Immigration and Refugee Policy: Australia and Canada Compared. (2 Volumes). Toronto: University of Toronto Press.

Adelman, H. (2001). From Refugees to Forced Migration: The UNHCR and Human Security. International Migration Review. 35(1), 7-32.

Aiken, S. (1999) Racism and Canadian Refugee Policy. Refuge. 18(4).

Angus Reid Poll (2009). Canadians Support Government on Visas for Mexican, Czech Nationals $<$ http://www.angusreidstrategies.com/uploads/pages/pdfs/2009.07.17 Visas.pdf $>$

Barnett, M., \& Finnemore, M., (2004) Rules for the World: International Organizations In Global Politics. New York: Comell University Press.

Biermann, F., Boas, I. (2008). Protecting climate refugees: the case for a global protocol. Environment Magazine. 50(6), 10-16

Black, J. \& Hicks, B. (2008). Electoral Politics and Immigration in Canada: How Does Immigration Matter? International Migration \& Integration 9, 241-267 Black, R (2001).Environmental refugees: myth or reality? UNHCR. New Issues in Refugee Research: Working Paper No. 34, 1-19 $<$ http://www.unhcr.org/3ae6a0d00.html $>$ 
Brouwer, A., Kumin, J. (2003).Interception and Asylum: When Migration Control and Human Rights Collide. Refuge, (21).4.

Brown, O. (2008). Migration and Climate Change. International Organization for Migration. Geneva

Canadian Council for Refugees. A hundred years of immigration to Canada. http://www.ccrweb.ca/history.html

Canadian Council for Refugees. (2009). $40^{\text {th }}$ Anniversary of signing the refugee convention. $<\underline{\text { http://ccrweb.ca/40thanniversary.htm }>}$

Castles, S., (2002). Environmental change and forced migration: making sense of the debate. UNHCR. New Issues in Refugee Research: Working Paper No. 70, 1-14

Chhabara, R. (2008). Climate change refugees seek a new international deal. Climate Change Corp. 27 Dec 2008 http://www.climatechangecorp.com/content.asp?contentid=5871

Cheran, R. (1999).In Search Of the African Queen. Film. TVO

Cheran, R. Lecture at Ryerson University. October 19, 2009

Chimni, B. S. (2000). Globalization, Humanitarianism and the Erosion of Refugee Protection. Journal of Refugee Studies. 13(3), 243-263.

Chope, (2009).United Kingdom, European Democrats Group. The challenges posed by Climate Change. Doc. 12040. 29 September 2009. Council of Europe. Parliamentary Assembly

CIC, "Fact Sheet: September 11, 2001, A Year Later." Retrieved September 2, 2009 $<$ http://www.cic.gc.ca/english/pub/sept11.html>

Cooper, J. (1998)."Environmental Refugees: Meeting the Requirements of the 
Refugee Convention." New York University Environmental Law Journal. 6, 480529.

http://www1.law.nyu.edu/journals/envtllaw/issues/vol6/2/6nyuelj480.html

Copenhagen Climate Council. Clear and Present Danger: A Conversation With Nobel Laureate Steve Chu on the Risks of Climate Change.

http://www.copenhagenclimatecouncil.com/get-informed/news/clear-and-present-dangera-conversation-with-nobel-laureate-steve-chu-on-the-risks-of-climate-change

Curry, B. (2009). Asylum Seekers' success rate plunges under Tory government. Globe \& Mail. November 3, 2009, p.A9.

Dauvergne, C. (1999). Amorality and Humanitarianism in Immigration Law. Osgoode Hall Law Journal, 37(3), 598-623.

Dauvergne, C. (2005). "Globalization and the Ironic Erosion of Refugee Law" Paper presented at the annual meeting of the International Studies Association, Hilton Hawaiian Village, Honolulu, Hawaii Online (GET PAPER) $<$ http:/www.allacademic.com/meta/p69469 index.html $>$

Dench, J., Crépeau, F. (2003).Interdiction at the Expense of Human Rights: A Long-term Containment Strategy. Refuge. 21(4) Introduction: 1-5

Dyer, G. (2008). Climate Wars. Canada: Random House Canada.

Ebell, M. (2009) Obama's climate fantasies. Financial Post. Wednesday, Sept. 23, 2009 www.nationalpost.com/todays-paper/story.html?id=2021747

European Council. (2008). Paper from the High Representative and the European Commission. Climate Change And International Security March 14, 2008. No. S113/08. http:/74.125.47.132/search?q=cache\%3AmAc3eOcGxjQJ\%3Awww.consilium.europa.e u \%2Fuedocs $\% 2 \mathrm{Fcms}$ data\%2Fdocs\%2Fpressdata\%2Fen\%2Freports\%2F99387.pdf +clim ate+change + migration + to $+E U \& h l=e n \& g l=c a$ 
Grant, H., Randerson, J., Vidal, J. (2009) UK should open borders to climate refugees, says Bangladeshi minister. guardian.co.uk. December 4, 2009. http://www.guardian.co.uk/environment/2009/nov/30/rich-west-climate-change

Finnemore, M. (1996). National interests in international society. New York. Cornell University Press.

Flannery, Tim. (2009, October 12). Interview broadcast in The Current. CBC Radio One. http://odeo.com/episodes/25284363-CBC-s-The-Current-Tim-Flannery-interview-frombroadcast-of-13-October-2009

Friedman, L. (2009).Adaptation: A city exploding with climate migrants. ClimateWire, March 16, 2009. http://www.eenews.net/public/climatewire/2009/03/16/1

Hamlin, R., (2009). Let me be a refugee: asylum seekers and the transformation of law in the United States, Canada, and Australia. (Doctoral dissertation in Political Science, 2009).University of California, Berkley.

Hatton, Timothy. (2009).The rise and fall of asylum: what happened and why? The Economic Journal. 119, F183-F213.

Hoadley, S. (2003). Immigration Policy: A steady compromise. New Zealand International Review. 28(2), 17-20.

Inglis, C., Birch, A. \& Sherington, G., (1994).An Overview of Australian and Canadian Migration Patterns and Policies. Immigration and Refugee Policy: Australia and Canada Compared. Toronto: University of Toronto Press.

Institute of Public Administration of Canada. (2008). Advice to Government: Climate Change and Canadian Public Policy: Adaptation and Action" Retrieved October 12, 2009 
www.ipac.ca/documents/AdvicetoGovernment.pdf

Jacobson, J. (1988). Environmental refugees: a yardstick of habitability. Washington:

Worldwatch Institute. Worldwatch paper 86.

Joly, Danièle. (2001).Convergence Towards a Single Asylum Regime: A Global Shift of

Paradigm. The International Journal of Human Rights. 5(4). 1-17

Kelley, N., \& Trebilcock, M. (1998). The Making of the Mosaic: A history of Canadian immigration policy. Toronto: University of Toronto Press

Knill, Christoph (2005).Cross-national policy convergence: concepts, approaches and explanatory factors. Journal of European Public Policy. 12(5), 764-774 http://dx.doi.org/10.1080/13501760500161332

Li, Peter (2003).Destination Canada: Immigration Debates and Issues. Don Mills: Oxford University Press.

Loescher, Gil (2001).The UNHCR and World Politics: State Interests vs. Institutional Autonomy. International Migration Review. 35(1) pp.35-56

Lovelock, J. (2009). The Vanishing Face of Gaia: A final warning. London: Allen Lane. Marfleet, P. (2006). Refugees in a Global Era. Hampshire: Palgrave Macmillan McMaster, Don, (2001). Asylum Seekers: Australia's Response to Refugees. Victoria: Melbourne University Press

McNamara, K. E., (2007). Conceptualizing discourses on environmental refugees at the United Nations. Population and Environment. 29, 12-24.

Milner, J. (2008). New Challenges in International Refugee Protection: Canada's Role. Presentation to the Canadian School of Public Service. October 9, 2008. http://canada.metropolis.net/mediacentre/new challenges internat refugee protection e. 
Myers, Norman (1993). Environmental Refugees in a Globally Warmed World.

BioScience , 43 (11), 752-761

Myers, $N$ (2002). Environmental Refugees: A Growing Phenomenon of the 21st Century.

Philosophical Transactions: Biological Sciences. 357 (1420) pp. 609-613

Nash, A., E. (1999).Environmental Refugees: Consequences and Policies

from a Western Perspective. Discrete Dynamics in Nature and Society, 3, 227-238

Nelson, D. (2009). A treaty for 'climate refugees'? One World UK

http://uk.oneworld.net/article/view/162390/1/

Nelson, D (2005).India fences off Bangladesh to keep out Muslim terror.

Timesonline. Dhaka November 13, 2005

<http://www.timesonline.co.uk/tol/news/world/article589627.ece>

Nessel, L. A. (2009). Externalized Borders And The Invisible Refugee. Columbia Human Rights Law Review, 55, 625-699.

Neumann, K. (2004). Refuge Australia: Australia's Humanitarian Record. Sydney: UNSW Press.

Now (2008). Paradise Lost. Transcript. December 12, 2008. Public Broadcasting Service (PBS).

http://www.pbs.org/now/shows/449/transcript.html

Pueblo Objectives 2002. Plan of action regional conference on migration (RCM)

27-29 November 2006

http://www.remvs.org/plande.htm

Raleigh, Clionadh., Jordan, Lisa. Salehyan, Idean. (2008?). Assessing the Impact of Climate Change on Migration and Conflict PRIO - International Peace Research 
Institute, Oslo for the World Bank.

$<$ http://74.125.95.132/search?q=cache:kksiq_wc13JJ:siteresources.worldbank.org/EXTS OCIALDEVELOPMENT/Resources/SDCCWorkingPaper MigrationandConflict.pdf + A ssessing+the+Impact+of+Climate+Change+on+Migration+and+Conflict+PRIO\&cd $=1 \&$ hl=en\&ct=clnk\&gl=ca\&client=firefox-a>

Solomon, L. (2009, Oct. 24). High risks in climate change policy. Financial Post

http://www.financialpost.com $/ \mathrm{m} /$ story.html?id=2139539\&s=Opinion

Squires, N. (2007, October 4). Australia 'in danger' from climate change refugees. nzherald.co.nz http://www.nzherald.co.nz/world/news/article.cfm?c id=2\&objectid=10467715

Stern, N (2006). Stern Review on the Economics of Climate Change. HM Treasury

Cabinet Office. Retrieved June 2008.

http://www.hm-treasury.gov.uk/sternreview_index.htm

Swan, M. (2009, November 06). Africa refugee processing inadequate. The Catholic Register, http://www.catholicregister.org/content/view/3573/849/

The Daily Star. (2009, October 23) Maldivians face life as 'climate refugees'

New Delhi.

http://www.thedailystar.net/story.php?nid=110981

Traynor, I. (2008) EU told to prepare for flood of climate change migrants

The Guardian. Monday 10 March 2008

UNHCR Policy Paper (2009a) Climate change, natural disasters and human displacement: a UNHCR perspective October 2009, UNHCR Policy Paper www.unher.org/climate.

UNHCR (2009b) Annual Report Of The UNHCR And Reports Of The Office Of The High Commissioner And The Secretary-General (January, 2009).Report of the Office of the UNHCR on the relationship between climate change and human rights. United Nations 
Human Rights Council.

UNHCR (2009c). 2008 Global Trends: Refugees, Asylum-seekers, Returnees, Internally Displaced and Stateless Persons. http://www.unhcr.org/4a375c426.html

UNHCR (2006) Number of asylum seekers halved since 2001, says UNHCR UNHCR: Press Releases, 17 March 2006.

http://www.unhcr.org/cgi-bin/texis/vtx/news/opendoc.htm?tbl=NEWS\&id=441a7d714

UNHCR Report. (2000). The State of the World's Refugees 2000: Fifty years of humanitarian action. Flight from Indochina. UNHCR http://www.unhcr.org/4a4c754a9.html

The Universal Declaration of Human Rights. United Nations. http://www.un.org/en/documents/udhr/index.shtml\#al4

Warner, K., Ehrhart, C., de Sherbinin, A., Adamo, S., Chai-Onn, T. (2009). In Search of Shelter: Mapping the Effects of Climate Change on Human Migration and Displacement http://ciesin.columbia.edu/publications.html.

Watson, S. (2006). The State and Refugee Identity: Reconstructing Humanitarianism. Paper presented at ISA San Diego, CA. Retrieved from http://www.allacademic.com/meta/p mla apa research citation/0/9/8/2/5/p98250 index. $\underline{\mathrm{html}}$

Williams, A. (2008).Turning the Tide: Recognizing Climate Change Refugees in International Law. Law \& Policy, 30, (4), 502-529 